\title{
ARAŞTIRMA/RESEARCH
}

\section{Anti-müllerian hormonunun in vitro fertilizasyon hastalarinda over rezervini belirlemedeki rolü}
The role of anti-mullerian hormone for determining the ovarian reserve of IVF patients

Haççe Yeniçeri ${ }^{1}$, İbrahim F. Ürünsak ${ }^{2}$, Mete Sucu², Cihan Çetin², Mehmet Özsürmeli2, Ghanim Khatib ${ }^{2}$

${ }^{1}$ Osmaniye Devlet Hastanesi Kadın Hastalıkları ve Doğum Bölümü. Osmaniye, Turkey

${ }^{2}$ Çukurova Üniversitesi Tıp Fakültesi Kadın Hastalıkları ve Doğum ABD. Adana, Turkey

\begin{abstract}
Purpose: The puspose of this study was to find the level of effectiveness and reliability of $\mathrm{AMH}$ (anti-müllerian hormone) in indicating the over reserve of IVF patients in comparison with other reserve indicators used.

Materials and Methods: The study included 89 infertile couples ages between 18 and 45. Basal serum FSH, LH, E2, prolactin, fT3, fT4 and TSH, AMH levels of female patients were measured in the 3rd day of menstruation. Ovary volume and AFC(antral follicle count) were determined through transvaginal ultrasound. In our study, all patients were subjected to long protocol with GnRH agonist. Oocyte numbers equal to or higher than 4 were included in the "good response" group and oocyte numbers lower than 4 were included in the "poor response" group. Afterwards, the results obtained were statistically compared with other parameters used for determination of ovarian reserve.
\end{abstract}

Cukurova Medical Journal 2017;42(1):19-26.

Results. Significant differences were present between two groups in terms of age, serum FSH, AMH levels, hCG day E2 levels, number of antral follicles, hCG day follicle numbers and mature oocyte numbers. When the cutoff value for $\mathrm{AMH}$ was taken to be $0,24 \mathrm{ng} / \mathrm{ml}$, sensitivity and specifity were determined to be $82.1 \%$ and $72.7 \%$ respectively.

Conclusion: There is a strong relationship between serum $\mathrm{AMH}$ level and the ovarian response of the patients. Besides, AMH levels were determined to be in relation with the pregnancy rate.

Key words: In Vitro fertilization, pregnancy, ovarian function tests
Öz

Amaç: Over rezervini belirlemede anti-müllerian hormonun(AMH) diğer kullanılan rezerv belirteçleriyle kıyaslayarak etkinlik ve güvenirliliğini tespit etmektir.

Gereç ve Yöntem: Çalışmaya yaşı 18-45 arası olan 89 infertil çift değerlendirmeye alındı. Hastaların adetinin 3.günü AMH, bazal serum FSH, LH, E2, prolaktin, sT3, sT4, TSH seviyeleri ölçüldü. Transvaginal ultrason ile over volümü ve antral folikül sayısı belirlendi. Çalışmamızda tüm hastalara GnRH agonisti ile long protokol uygulandı. Hastalar toplanan oosit sayısına göre $\geq 4$ (iyi yanıt) ve $<4$ (kötü yanıt) olarak 2 gruba ayrildı. Daha sonra elde edilen sonuçlar over rezerv tespitinde kullanılan diğer parametrelerle istatistiksel olarak karşılaştırıldı.

Bulgular: İki grup arasında yaş, serum FSH, AMH düzeyleri, hCG günü E2 düzeyleri, antral folikül sayıs1, hCG günü folikül sayısı, matür oosit sayısı istatistiksel olarak anlamlı farklılık göstermiștir. AMH için eșik değeri $0,24 \mathrm{ng} / \mathrm{ml}$ alındığı zaman sensitivitesi $\% 82.1$; spesifitesi $\% 72.7$ olarak saptand. AMH en yüksek sensitivite ve spesifiteye sahip bulundu.

Sonuç: Serum AMH seviyesi ile over cevabi arasinda kuvvetli ilişki olduğunu gördük. Aynı zamanda yüksek AMH seviyeleri gebelik başarısıyla da ilişkilidir. Ancak canlı doğumla AMH arasında herhangi bir ilişki saptanmamışır.

Anahtar kelimeler: Gebelik, in vitro fertilizasyon, ovaryum fonksiyon testleri 


\section{GİRİ̧̧}

Günümüzde infertil hastaların tedavisinde önemli gelişmeler elde edilmiştir. Özellikle yardımcı üreme tekniklerinin gelişmesiyle infertilite tedavisindeki başarı oranı artmış ve daha çok infertil çiftin sağlıklı bir bebeğe sahip olabilmesi sağlanmıştır. Tedavinin başarısı, hastaların uygun olarak değerlendirilmesine, uygun tedavinin planlanmasina, uygun tekniklerin kullanılmasına ve hasta uyumuna bağlıdır. Tüm bu aşamalarda hastaların bazal olarak doğru değerlendirilmesi, semen kalitesi ve over rezervinin saptanması çok önemlidir ${ }^{1,2}$.

Over rezervi oosit sayısı ve kalitesiyle ilgilidir ve kadının reprodüktif potansiyelini gösterir ${ }^{2}$. Over rezervinin gösterilmesi klinisyenin başarı şansı konusunda hastanın bilgilendirilmesini sağlar. Böylece over rezervinin kötü olduğu hastaların başarısız bir tedavi siklusu yaşamasından kaynaklanan emosyonel stres, maddi kaynaklarının boşa harcanması ve zaman kaybı önlenmiş olur. Bunun yanısıra tedaviden fayda görebilecek hastaların da tedavi programında tutulması sağlanır. Yapılan çalışmalarda infertilite insidansı 20- 24 yaş için \% 6, 30- 34 yaş için \%15, 35- 39 yaş aralığ için $\% 30$ ve 40- 44 yaş aralığı için ise 64 olarak verilmektedir ${ }^{1}$.

Ovaryan rezerv, oositlerin kalite ve sayısını yansıtan ve overin fonksiyonel potansiyelini tanımlamak için kullanılan bir terimdir. İyi bir ovaryan rezerv testi;

- Tedavi ile veya tedavi yapilmaksizın konsepsiyon olasılığını tespit edebilmeli,

- Canlı doğum şansını belirleyebilmeli

- Ölçülen bu aktivitenin overyan yaşlanma gerçekleşmeden ne kadar süre aynı düzeyde devam edebileceğini öngörebilmeli

- Planlanan overyan stimülasyon protokolünde optimal dozu belirlemede ve bireysel prognozu öngörmede yol gösterici olmalıdır ${ }^{2}$.

Over rezervi bilindiği gibi doğumdan itibaren yaşla azalmakta, 35 yaşından sonra oosit kalitesi de bozulmaktadır ${ }^{3}$. İleri yaşlarda yardımcı üreme teknikleri ile elde edilen oositlerde tipik morfolojik değişiklikler görülmektedir. Rezerv azalmasının mekanizması tam bilinmemektedir. Fakat çevresel faktörlerin etkisiyle oksidatif hasar ve hormonal dengesizlik folikülü atreziye götürmektedir. Bugüne kadar literatürde overyan rezervi değerlendirmek için çok sayıda test ve belirteç tanımlanmıştır. Over rezervi testleri, statik ve dinamik testler olarak gruplandirilir ${ }^{4}$.

Statik testlerarasında yaş, serum bazal folikül stimülan hormon(FSH), estradiol(E2), inhibin- B, anti-müllerian hormon $(\mathrm{AMH})$ seviyeleri; ultrasonografik ovaryan hacim, bazal antral folikül sayısı(AFC), overyan stromal kan akımı ölçümleri; overyan biyopsi bulunmaktadir4.Dinamik testler arasinda ise Klomifen sitrat testi (CCCT); GnRH agonist stimulasyon testi (GAST) ve eksojen FSH overyan rezerv test (EFORT) sayllabilir ${ }^{4}$.

Halen tüm dünyada over rezervini belilemede kesin bir standartizasyon yapılmamıştır. En güvenilir parametrenin ne olduğu konusunda tartışmalar sürmektedir. $\mathrm{Bu}$ bağlamda yakın zamanda Transforme edibi büyüme faktörü -beta (TGF- $\beta$ ) ailesinin bir üyesi olan AMH over rezervinin belirteci olarak ileri sürülmüştür ${ }^{3,4}$.

Kadında serum AMH düzeyleri erkeğe göre daha düşüktür. Puberte sonrası, menstrüel siklüs başladığında sirkülasyondaki serum AMH düzeyi giderek azalır ve menopozda tespit edilemez hale gelir ${ }^{4}$. Spontan menopoz ve ooferektomi sonrasinda $\mathrm{AMH}$ düzeylerinin serumda tespit edilemeyecek düzeylere düssmesi AMH'nın tamamen over kaynaklı olduğunu göstermektedir. AMH ile ilgili yapılan temel çalışmalar AMH'nın foliküler hormon yapımında etkili olduğunu ve folikülogenez sirasinda, preantral ve erken antral foliküllerden salındığını göstermiştir ${ }^{5}$. Çalışmamızın amacı,over rezervini belirlemede AMH'nu diğer kullanılan rezerv belirteçleriyle kıyaslayarak etkinlik ve güvenirliliğini tespit etmektir.

\section{GEREÇ VE YÖNTEM}

\section{Hasta seçimi}

Çalışmamız Eylül 2009- Temmuz 2010 tarihleri arasında Çukurova Üniversitesi Tıp Fakültesi Kadın Hastalıkları-Doğum Kliniğinin Üremeye Yardımcı Tedavi Merkezinde prospektif kohort çalışması olarak yürütüldü. Çalışmaya başlanmadan önce Çukurova Üniversitesi Bilimsel Araştırma ve Yayın Etik Kurul etik onayı alındı. Hastalardan bilgilendirilmiş onam alındı. 18-45 yaş arası kriterlere uygun 89 infertil çift değerlendirmeye alınd. Çalışmaya adetin 2-3.gün ölçülen serum $\mathrm{FSH}<15$ $\mathrm{IU} / \mathrm{ml}$ ve $\mathrm{E} 2<80 \mathrm{pg} / \mathrm{ml}$ olan hastalar dahil edildi. Dişlama kriterleri Tablo 1'de belirtilmiştir.Transvajinal ultrasonografi ile over 
volümü ve antral follikül sayısı belirlendi. Histerosalpingografi ile endometrial kavite ve tubalar değerlendirildi. Hastalar; erkek faktörü, yaş faktörü (38 ve üstü yaş grubu), açıklanamayan faktör, tubal faktör endikasyonları nedeniyle in vitro fertilizasyon-intrasitoplazmik sperm enjeksiyonuembryo transferi (IVF-ICSI-ET) için hazırlandı.

Tablo 1. Dişlama kriterleri

\begin{tabular}{l} 
Polikistik over sendromu \\
\hline Hipotiroidi \\
\hline Hipertiroidi \\
\hline Hipogonadotropik hipogonadizm \\
\hline Hipergonadotropik hipognadizm \\
Adrenal bez hastalıkları (Cushing sendromu, Addison \\
vs.) \\
\hline Müllerian anomaliler
\end{tabular}

\section{Ovulasyon indüksiyon protokolü}

Çalışmamızda tüm hastalara gonadotropin salgılatıcı hormon $(\mathrm{GnRH})$ agonisti ile uzun protokol uyguland1. Tedaviye bir önceki siklusun 21. gününde GnRH anologu (löprolid asetat-Lucrin ${ }^{\text {TM }}$, Triptorelin asetat- Decapeptyl ${ }^{\mathbf{T M}}$ ) Lucrin $^{\mathbf{T M}} 1$ $\mathrm{mg} /$ gün, Decapeptly ${ }^{\mathbf{T M}} \quad 0,1 \mathrm{mg} /$ gün dozunda subkutan olarak başlandi. Hastalar adetin 2-3. gününde hipofizer down regulasyonun olup olmadığının belirlenmesi için çağrıldı. Transvajinal ultrasonografide foliküler aktivitenin olmaması ve serum E2'nin $80 \mathrm{pg} / \mathrm{ml}$ altında olmas1 down regülasyon olarak kabul edildi. Prematür luteinizan hormon (LH) yükselmelerini önlemek amaciyla hCG gününe kadar $\mathrm{GnRH}$ anoloğunun dozu yarlya düşülerek devam ettirildi. Gonadotropin dozu; hastanın yaşı, kilosu, bazal E2, FSH seviyesine, over volümüne ve varsa daha önceki ovulasyon indüksiyonu cevabına bakılarak belirlendi.

Seri ultrasonografi kontrolleri ve serum E2 kontrollerinden sonra 18 mm'den büyük en az 2-3 folikül geliştiği hastalarda oosit toplama işlemi planlandi.

\section{Oosit toplanmas1}

Oosit toplama işlemi, insan koryonik gonadotropin (hCG) dozundan itibaren 35-37. saatte yapild1.6.5 Mhz'lik vajinal prob (Medison Digital Sonoace $5500^{\mathrm{TM}}$ ), iğne (MDT-Medical development 8 Technology BUTM 17 gauge / 15x300mm) ve aspiratör (Labotect Aspirator 4014 ${ }^{\mathrm{TM}}$ ) kullanıldı.
Oositler gelişimine göre GV, MI, MII olarak sınıflandırıldı. M2 (matur oosit) ICSI için hazırlandı.

$\mathrm{Bu}$ arada erkekten alınan semen, işlemden geçirilerek yüzdürüldü. Azospermi olan hastalara ürolog tarafindan testiküler sperm ekstraksiyonu (TESE) işlemi uygulandı.Oosit toplanmasından itibaren 2 ya da 3. gün embriyo transferi uygulandı.Embriyo transferinden 12 gün sonra $\beta$-hCG bakıldı. Çalışmamızda toplanan oosit sayısının $\geq 4$ olması başarılı sonuç olarak kabul edildiğinden olgular toplanan oosit sayısına göre iki gruba ayrılmış ve ölçülen parametrelerin ortalamaları bu iki grup için karşılaştırılmıştır.

\section{AMH ölçümü}

Gebeliğin elde edilmesi; over rezervinin yanısıra erkek faktörü, endometrium yapısı gibi diğer birçok faktörden etkilendiğinden, literatüre uygun olarak tedavinin başarısını toplanan oosit sayısına göre değerlendirdik. Tedavi sonunda toplanan oosit sayısının $>=4$ olduğu 67 hastanın tedaviye yanıtı iyi, $<4$ olan 22 hastanın cevabı kötü olarak değerlendirildi. $\mathrm{Bu}$ amaçla hastalardan menstrüasyonun 2. veya 3 . günü $5 \mathrm{ml}$. tam kan alınarak 3500 devir hızında 10 dakika santrifüj yapıldı. Elde edilen serumlar 1.5 ml'lik polipropilen tüplerde $-80^{\circ} \mathrm{C}$ sıcaklı̆̆ındaki buzdolabında saklandi. Ağustos 2010'da saklanan tüm serumlar, ELISA yöntemiyle Diagnostik Systems Laboratories Inc.(Teksas, ABD) firmasina ait, ACTIVE MIS/AMH ELISA DSL-10-14400 ${ }^{\text {TM }}$ adlı kit kullanılarak çalışıldı ve AMH düzeylerinin ölçümü yapild1.

\section{İstatistiksel analiz}

Verilerin istatistiksel analizinde Statistical Package for the Social Sciences (SPSS)v15.0 Evaluation paket programı kullanıldı. Kategorik ölçümler sayı ve yüzde olarak, sürekli ölçümlerse ortalama ve standart sapma (gerekli yerlerde ortanca ve minimum maksimum) olarak özetlendi. Kategorik ölçümlerin gruplar arasında karşılaştırılmasında Ki Kare test istatistiği kullanıldı.

Gruplar arasinda sürekli ölçümlerin karşılaştırılmasında varsayımların sağlanması durumunda bağımsız gruplarda t testi, varsayımların sağlanmaması durumunda ise Mann Whitney $U$ ve Kruscal Wallis + Medyan testi kullanıldı. Korelasyon analizi ve ROC eğrileri oluşturularak araştırılan paremetrelerin prediktif değerleri karşılaştırıldı. 89 
hasta sayısı istatiksel gücü karşıladığ1 için yeterli kabul edildi. Tüm testlerde istatistiksel önem düzeyi 0,05 olarak alındi.

\section{BULGULAR}

Çalışma grubundaki 89 hastanın demografik özellikleri Tablo 2'de gösterilmiştir.Hastaların bazal hormon düzeyleri, hCG günü bu düzeylerde oluşan değişiklikler, USG'de ölçülen over volümü, antral folikül sayıları Tablo 3'de gösterilmiştir. Tablo 4'de görüldüğü üzere her iki grup arasında infertilite süresi, vücut kitle indeksi, LH ve E2 düzeyleri açısından anlamlı fark görülmemiştir. Aynı zamanda iki grupta yaş, serum bazal FSH ve AMH düzeyleri, hCG günü E2 düzeyleri, antral folikül sayısı, hCG günü folikül sayısı ve matür oosit sayısı ortalamaları istatistiksel olarak anlamlı farklılık göstermektedir. Toplanan oosit sayısı ile ölçtügüümüz parametrelerin korelasyonuna bakıldığında yaş, bazal FSH, AMH, antral folikül sayısı, matür oosit düzeylerinin korelasyonu anlamlıdır. Toplanan oosit sayısı ile E2 arasinda anlamlı korelasyon yoktur (Tablo 5).

ROC eğrisi kullanılarak 3.gün AMH, FSH, E2 düzeyleri ve antral folikül sayısı için toplanan oosit sayısının $<4$ veya $=>4$ olmasına göre sensitivite ve spesifite hesabı yapılarak grafik çizildi.(Şekil 1)AMH için cut off değeri $0.24 \mathrm{ng} / \mathrm{ml}$ alındığı zaman sensitivitesi $\%$ 82.1; spesifitesi $\% \quad 72.7$ olarak saptand. Pozitif prediktif değer \% 90.2; negatif prediktif değer \% 57.1 olarak belirlendi. AMH en yüksek sensitivite ve spesifiteye sahip bulundu. ROC eğrisinde en üstte AMH düzeyinin yer aldığını, bunu antral folikül sayısı, E2 ve FSH'ın izlediğini gördük (Şekil 1).

$\mathrm{AMH}>0.24 \mathrm{ng} / \mathrm{ml}$ olan hastalarda alınan over cevab1 \% 90.2 başarılı iken, $\mathrm{AMH}<0.24 \mathrm{ng} / \mathrm{ml}$ olanlarda ise bu oran ancak \% 42.9 olarak tesbit edildi, bu fark istatistiksel olarak anlamlı bulundu $(\mathrm{p}<0.001)$ (Tablo 6). Tedavi sonucunda 27 (\% 30.3) olguda gebelik elde edildi. Bunlardan biri üçüz, 2'si ikiz, 16's1 tekiz olmak üzere 19 (\%21.3) gebe canlı doğum yapmıştır. 5 gebelik abortusla sonuçlanmıştır. 3 gebelikte ise biyokimyasal gebelik oluşmuştur. Çalışmaya katılan hastalarda oluşan gebelik sayısı ile over cevabı arasındaki ilişki Tablo 7'de gösterilmiştir.

AMH için cut off değeri $0.24 \mathrm{ng} / \mathrm{ml}$ alındığında oluşan gebelikler Tablo 8'de gösterilmiştir. $\mathrm{AMH}>0.24 \mathrm{ng} / \mathrm{ml}$ olan grupta 24 (\% 39.3), diğer grupta ise $3(\%$ 10.7) gebelik izlendi ve $p=0.006$ idi gruplar istatistiksel olarak farkl1 bulunmuştur.AMH $>0.24 \mathrm{ng} / \mathrm{ml}$ olan grupta $17(\%$ 27.8) canlı gebelik, diğer grupta ise 2 (\% 7.1) canlı gebelik izlendi ve $\mathrm{p}=0.075 \mathrm{idi}$ ve gruplar istatistiksel olarak farklı bulunmamıştır.

\section{TARTIŞMA}

Over rezervini değerlendirmede kullanılacak ideal belirteç ucuz, kolay ölçülebilen, minimal invazif, prediktif değeri iyi olmalıdır. 3. gün bakılan FSH ve E2 değerleri over rezervini gösteren indirekt belirteçlerdir. ${ }^{6}$ Yaşla beraber mevcut oosit sayı ve kalitesinde azalma olduğu ve paralel olarak bazal FSH düzeylerinin yükseldiği bilinmektedir. Menstrüasyon over rezervinin kaba bir göstergesidir ve kritik olarak azalmış over rezervine rağmen hastalar adet görmeye devam edebilirler ${ }^{7}$. İleri yaşlarda E2, hipofizer FSH sekresyonu ile korelasyon göstermemektedir. Bu nedenle Klomifen sitrat challenge test, $\mathrm{GnRH}$ agonist stimülasyon testi gibi provakatif testler geliştirilmiştir ${ }^{8}$

Halen over rezervinin tayininde daha iyi belirleyiciler bulmak için çalışmalar devam etmektedir. Bunlara örnek olarak; aktivin, folistatin, inhibin B sayılabilir. Son yllarda ise AMH'un over rezervinini belirlemedeki önemi gittikçe daha fazla anlaşılmaya başlanmıştır ${ }^{5,9,10}$. AMH, Lee ve arkadaşları tarafindan 20 y1l önce insan serumunda tespit edilmiştir ${ }^{11,12}$. IVF sikluslarında serum AMH seviyeleri ile yapılan çalışmalarla AMH'nın over rezerv testi olarak kullanımı değerlendirilmektedir.

Rooij ve arkadaşları yaptıkları çalışmada IVF tedavisi sirasindaki overyan cevap ve AMH düzeylerini araştırdılar. Over cevabı, dolayısıyla elde edilen oosit sayısı ile AMH arasında kuvvetli bir ilişki olduğunu buldular ${ }^{5}$. Dolayssiyla, AMH'nın over rezervini gösteren ümit verici bir prediktor olduğu sonucuna vardılar. Fanchin ve ark.yaşları 25-40 olan 47 normo-ovulatuar infertil hastada over rezervini belirlemede, birbirini takip eden üç menstrual siklusta, AMH, bazal FSH, inhibin-B, E2 konsantrasyonlarını ve bazal AFC' yi kullanarak yaptıkları çalışmada, en iyi ve en cost- efektif belirteçin AMH olduğunu bildirdiler ${ }^{13}$. Ayrıca AMH'nın diğer hormonal parametreler içinde sikluslar arası en az değişkenlik gösteren belirteç olduğunu gösterdiler. Bunun sebebi AMH salınımını gonadotropinlerden bağımsız iken, diğer hormonal parametrelerin konsantrasyonlarınin ise birbiri ile ilişkili olmasına bağladılar. 
Muttukrishma ve arkadașları 69 IVF hastası üzerinde yaptıkları çalışmada AMH' nın FSH ve inhibin-B' ye göre, gonadotropinlerle ovulasyon indüksiyonuna verilen cevabı değerlendirmede ve matür oosit sayısı ile en iyi korelasyon gösteren belirteç olduğunu rapor ettiler ${ }^{14}$. Fiçicioğlu ve ark. ve Jesper ve ark. ise erken foliküler AMH konsantrasyonlarının gonadotropinlere overyan cevab1 ve toplanacak matür oosit sayısını belirlemede diğer testlere oranla daha efektif olduğunu buldular ${ }^{15,16}$. Ancak gebelik başarısı ile AMH konsantrasyonları arasında bir ilişki olmadığı sonucuna vardılar. Bu çalışmada literatürle uyumlu olarak $^{5,9,10}$ AMH ile antral folikül sayısı ve toplanan oosit sayısıyla güçlü ilişki göstermiştir.

IVF sonrası gebelik oluşmasını tahmin etmede AMH kullanımı kisıtlıdır. AMH sadece overyan rezervi kantitatif olarak gösterir. Fakat gebelik oluşması oosit kalitesi, embriyo gelişimi ve endometrium yanıtına bağlıdır. $\mathrm{Bu}$ yüzden bazı çalışmalar serum AMH düzeylerinin oosit sayısını tahmin etmede uygun olduğunu, gebelik olasıllı̆gnı tahmin etmediğini göstermiştir. ${ }^{15-18}$

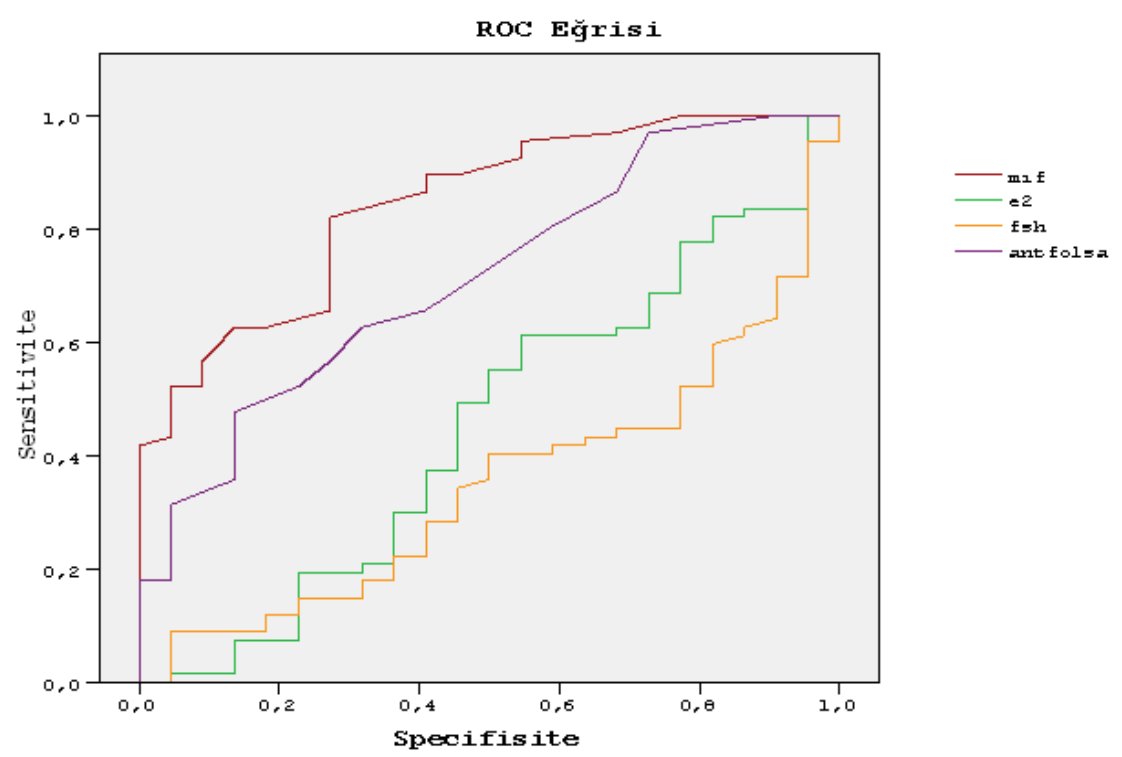

Şekil 1. FSH, E2, AMH(=MIF) ve Antral folikül ROC eğrileri

FSH:follikül stimülan hormon, E2: östradiol, AMH(MIF):anti-müllerian hormone

Tablo 2. Hastaların demografik özellikleri

\begin{tabular}{|l|c|}
\hline Özellikler & Ortalama \pm SS(min-maks) \\
\hline Yaş & $31.4 \pm 4.9(18-44)$ \\
\hline İnfertilite süresi (y1) & $7.6 \pm 4.9(1-21)$ \\
\hline VKİ $\left(\mathrm{kg} / \mathrm{m}^{2}\right)$ & $26.6 \pm 4.6(17.3-42.9)$ \\
\hline VKİंvücut kütle indeksi
\end{tabular}

VKİ:vücut kütle indeksi

Tablo 3. Hastaların over rezerv testleri sonuçları

\begin{tabular}{|l|c|}
\hline Özellikler & Ortalama \pm SS(Min-Maks) Ortanca \\
\hline FSH $(\mathrm{mIU} / \mathrm{ml})$ & $6.59 \pm 1.71(3.55-12.9) 6.54$ \\
\hline $\mathrm{E} 2(\mathrm{pg} / \mathrm{ml})$ & $39.18 \pm 16.89(9.41-77.20) 35.90$ \\
\hline $\mathrm{LH}(\mathrm{mIU} / \mathrm{ml})$ & $5.78 \pm 2.73(0.1-16.88) 5.04$ \\
\hline $\mathrm{AMH}(\mathrm{ng} / \mathrm{ml})$ & $1.64 \pm 2.06(0.05-10) 0.95$ \\
\hline Over volümü $(\mathrm{mm} 3)$ & $6.83 \pm 3.06(2.1-19) 6.60$ \\
\hline hCG günü E2 düzeyi & $1774.81 \pm 996.68(239-5100) 1594.00$ \\
\hline Antral folikülsayis1 & $9.33 \pm 6.36(1-24) 7.00$ \\
\hline
\end{tabular}

FSH:follikül stimülan hormon, E2: östradiol, LH: lüteinizan hormone, AMH:anti-müllerian hormone, hcg:insan koryonik gonodotropin 
Tablo 4. Hastalarındemografik özelliklerinin ve rezerv testlerinin over cevabına göre karşılaştırılması

\begin{tabular}{|l|c|c|c|}
\hline Özellikler & $\begin{array}{c}\text { Over cevab1<4 (n=22) } \\
\text { Ortalama } \mathbf{s S}\end{array}$ & $\begin{array}{c}\text { Over cevabi } \geq \text { 4(n=67) } \\
\text { Ortalama } \pm \text { SS }\end{array}$ & $\mathbf{p}$ \\
\hline Yaş & $33.68 \pm 4.95$ & $30.76 \pm 4.76$ & 0.027 \\
\hline İnfertilite süresi (yıl) & $8.27 \pm 5.66$ & $7.43 \pm 4.67$ & 0.867 \\
\hline $\mathrm{VKI}\left(\mathrm{kg} / \mathrm{m}^{2}\right)$ & $26.77 \pm 5.39$ & $26.57 \pm 4.45$ & 0.819 \\
\hline $\mathrm{FSH}(\mathrm{mIU} / \mathrm{ml})$ & $7.25 \pm 1.76$ & $6.37 \pm 1.64$ & 0.036 \\
\hline $\mathrm{E} 2(\mathrm{pg} / \mathrm{ml})$ & $41.94 \pm 19.72$ & $38.28 \pm 15.91$ & 0.487 \\
\hline $\mathrm{LH}(\mathrm{mIU} / \mathrm{ml})$ & $5.65 \pm 1.98$ & $5.83 \pm 2.94$ & 0.779 \\
\hline $\mathrm{AMH}(\mathrm{ng} / \mathrm{ml})$ & $0.38 \pm 0.47$ & $2.05 \pm 2.21$ & 0.001 \\
\hline hCG günü E2 düzeyi $(\mathrm{pg} / \mathrm{ml})$ & $822.18 \pm 400.83$ & $2087.62 \pm 933.56$ & 0.001 \\
\hline Antral folikül sayıs1 & $5.86 \pm 4.23$ & $10.47 \pm 6.55$ & 0.002 \\
\hline hCG günü folikül sayıs1 & $3.59 \pm 1.79$ & $9.19 \pm 4.37$ & 0.001 \\
\hline Matür oosit sayıs1 & $1.72 \pm 1.03$ & $7.47 \pm 3.84$ & 0.001 \\
\hline
\end{tabular}

VKİ:vücut kütle indeksi, FSH:follikül stimülan hormon, E2: östradiol, LH: lüteinizan hormone, AMH:anti-müllerian hormon, hcg:insan koryonik gonodotropin

Tablo 5. Toplanan oosit sayısı ile diğer parametreler arasındaki korelasyon

\begin{tabular}{|l|c|c|}
\hline Toplanan oosit & r & $\mathbf{p}$ \\
\hline Yaş & $-0,219$ & 0,039 \\
\hline FSH $(\mathrm{mIU} / \mathrm{ml})$ & $-0,380$ & 0,001 \\
\hline E2 $(\mathrm{pg} / \mathrm{ml})$ & $-0,127$ & 0,237 \\
\hline AMH $(\mathrm{ng} / \mathrm{ml})$ & 0,555 & 0,001 \\
\hline Antral folikül sayıs1 & 0,433 & 0,001 \\
\hline Matür oosit sayıs1 & 0,966 & 0,001 \\
\hline
\end{tabular}

FSH:follikül stimülan hormon, E2: östradiol, AMH:anti-müllerian hormone

Tablo 6. AMH düzeyi ile over cevabının değerlendirilmesi

\begin{tabular}{|l|c|c|c|}
\hline & $\begin{array}{c}\text { Over cevab1 <4 } \\
\mathbf{n}(\%)\end{array}$ & $\begin{array}{c}\text { Over cevab1 =>4 } \\
\mathbf{n}(\%)\end{array}$ & $\begin{array}{c}\text { Toplam } \\
\mathbf{n}(\%)\end{array}$ \\
\hline $\mathrm{AMH}<0.24 \mathrm{ng} / \mathrm{ml}$ & $16(57)$ & $12(43)$ & $28(100)$ \\
\hline $\mathrm{AMH}>0.24 \mathrm{ng} / \mathrm{ml}$ & $6(9)$ & $55(91)$ & $61(100)$ \\
\hline Toplam & 22 & 67 & 89 \\
\hline
\end{tabular}

AMH:anti-müllerian hormone

Tablo 7. Over cevabına göre gebelik durumunun değerlendirilmesi

\begin{tabular}{|l|c|c|c|}
\hline & $\begin{array}{c}\text { Gebelik var } \\
\mathbf{n}(\mathbf{\%})\end{array}$ & $\begin{array}{c}\text { Gebelik yok } \\
\mathbf{n}(\mathbf{\%})\end{array}$ & $\begin{array}{c}\text { Toplam } \\
\mathbf{n}(\mathbf{\%})\end{array}$ \\
\hline Over cevab1 $<4$ & $4(18)$ & $18(82)$ & $22(100)$ \\
\hline Over cevabi $\geq 4(\mathrm{n}=67)$ & $23(34)$ & $44(66)$ & $67(100)$ \\
\hline Toplam & 27 & 62 & 89 \\
\hline
\end{tabular}

Tablo 8. AMH düzeyi ve canlı doğumilişkisinin değerlandirilmesi

\begin{tabular}{|l|c|c|c|c|}
\hline & $\begin{array}{c}\text { Canlı Doğumla } \\
\text { sonuçlanan } \\
\text { gebelik } \\
\mathbf{n}(\mathbf{\%})\end{array}$ & $\begin{array}{c}\text { Canlı Doğumla } \\
\text { sonuçlanmayan } \\
\text { gebelik } \\
\mathbf{n}(\mathbf{\%})\end{array}$ & $\begin{array}{c}\text { Gebelik yok } \\
\mathbf{n}(\mathbf{\%})\end{array}$ & $\begin{array}{c}\text { Toplam } \\
\mathbf{n}(\mathbf{\%})\end{array}$ \\
\hline $\mathrm{AMH}<0.24 \mathrm{ng} / \mathrm{ml}$ & $2(7)$ & $1(4)$ & $25(89)$ & $28(100)$ \\
\hline $\mathrm{AMH}>0.24 \mathrm{ng} / \mathrm{ml}$ & $17(28)$ & $7(12)$ & $37(60)$ & $61(100)$ \\
\hline Toplam & 19 & 8 & 62 & 89 \\
\hline
\end{tabular}

AMH:anti-müllerian hormone 
Fakat bu çalışmada yüksek serum AMH düzeyleri elde edilen gebelik oranlariyla da korele iken canlı doğum oranlarını predikte etmede yetersiz bulunmuştur. Bazı çalışmalarda AMH düzeyleri ile IVF sonrası canlı doğum oranları ilişkili bulunmuştur ${ }^{19,20}$. Tsakos ve arkadaşları yaptıkları bir çalışmada Gnrh-antagonist IVF-ET protkollerinde overyan yanıtı belirlemede AMH düzeylerinin ve antral follikül sayımının iyi birer prediktör olduğunu gösterdiler ${ }^{21}$.

Demirtaş ve arkadaşlarının yaptı̆̆ı çalışmada AMH seviyelerinin yaş ve antral follikül sayısı ile korrele olduğu fakat $\mathrm{rFSH}$ ve klomifen sitrat ile tedavi edilen ovulatuar intrauterin inseminasyon(IUI) hastalarında over cevabinı tahmin etmede anlamlı olmadığı bulunmuştur ${ }^{22}$.

AMH değeri laboratuvar ortamında elde edilen objektif bir ölçümdür. Bu yüzden araştırmacılar arası değişkenlikten ve kişisel yorumlardan bağımsızdır. Buna karşın antral folikül sayısı tespiti USG ile yapılır. USG değerlendirmesinde kişisel farklılıklar olabilir. Antral folikül sayısı hem klinisyenin deneyimine hem de kullanilan cihazın kalitesine bağlıdır. Bu da antral folikül sayısının over rezervini değerlendirmede subjektif bir yöntem olduğunu göstermektedir. Antral follikül sayısının ivf siklusu öncesi belirlenmesinin klinisyenin embriyo kalitesi ve gebelik anlamında daha başarılı sonuçlar elde etmesine yardımcı olabileceğini gösteren çalışmalar vardır ${ }^{23}$. Infertiliteyi ve canlı gebelik sonuçlarını etkileyen uterin faktör, tubal faktör, ovaryan faktör ve erkek faktörü gibi birçok etmen vardır. $\mathrm{AMH}$ sadece ovaryan rezervin kantitatif değerlendirilmesinde kullanılan bir parametredir. $\mathrm{Bu}$ çalışmanın kısıtlılı̆̆1 ise heterojen bir grupta çalışılmış olmasıdır. Daha çok sayının olduğu homojen bir hasta grubunda yapilacak daha ileri çalışmalara ihtiyaç vardır.

Sonuç olarak AMH'nun diğer serum belirteçlerine göre birçok avantajı vardır. Öncelikle serum FSH ve inhibin B düzeyleri anormal düzeylere gelmeden $\mathrm{AMH}$ seviyeleri düşmeye başlar $^{22}$. Sadece erken foliküler fazda bak1labilen diğer parametrelere göre siklusun herhangi bir zamanında bakılabilir. Son olarak da AFC ölçümüne göre serum AMH analizi araştırmacıya bağımlı değildir ve daha az araştırmacılar arası değişkenlik gösterir.AMH'nın yardımcı üreme tekniklerinde gebelik oranını öngörmede etkinliğini değerlendiren daha fazla randomize çalışmaya hala ihtiyaç vardır.

\section{KAYNAKLAR}

1. Menken J, Trussel J, Larsen U. Age and infertility. Science 1986;233:1389-94.

2. Abna Maheshwari, Paul Fowler and Sladitya Bhattacharya. Assesment of ovarian reserve-should we perform testts of ovarian reserve routinely. Hum Rep. 2001;16:2729-35.

3. Oktem O, Oktay K. The Ovary: Anatomy And Function Throughout Human Life Ann N Y Acad Sci. 2008;1127:1-9.

4. Teixeria J, Maheswaran S, Donahoe PK. Müllerian inhibiting substance: an instructive developmental hormone with diagnostic and possible therapeutic applications. Endocrinol Rev. 2001;22:657-74.

5. I.A.J. van Rooij, F.J.M. Broekmans, E.R.te Velde, B.C.J.M. Fauser. Serum anti-Müllerian hormone levels: a novel measure of ovarian reserve. Hum Reprod. 2002;17:3065-71.

6. Ficicioglu C. Over rezervi ve reprodüktif rezerv tayini. Klinik Bilimler Dergisi. 1996;10:173-6.

7. Reh A, Oktem O, Oktay K. Impact of breast cancer chemotherapy on ovarian reserve: a prospective observational analysis by menstrual history and ovarian reserve markers. Fertil Steril. 2008;90:1635-9.

8. Navot D, Rosenwaks S, Margalioth E. J. Prognostic assessment of female fecudity. Lancet. 1989;2:645-7.

9. Hazout A, Bouchard P, Seifer DB, Aussage P, Junca AM. Serum antimüllerian hormone/müllerianinhibiting substance appears to be a more discriminatory marker of assisted reproductive technology outcome than follicle-stimulating hormone, inhibin B or estradiol. Fertil Steril. 2004;82:1323- 9.

10. Bath LE, Wallace WH, Shaw MP, Fitzpatrick C, Anderson RA. Depletion of ovarian reserve in young women after treatment for cancer in childhood: detection by anti-Müllerian hormone, inhibin-B and ovarian ultrasound. Hum Reprod. 2003;18:2368-74.

11. Lee MM, Donahoe PK. Mullerian inhibiting substance: a gonadal hormone with multiple functions. Endocr Rev. 1993;14:152-64.

12. Lee MM, Donahoe PK, Hasegawa T, Silverman B, Crist GB, Best S, Hasegawa Y, Noto RA, Schoenfeld D, MacLaughlin DT. Mullerian inhibiting substance in humans: normal levels from infancy to adulthood. J Clin Endocrinol Metab 1996;81:571-6.

13. Fanchin R, Taieb J, Lozano DH, Ducot B, Frydman $\mathrm{R}$, Bouyer J. High reproducibility of serum antiMullerian hormone measurements suggests a multistaged follicular secretion and strengthens its role in the assessment of ovarian follicular status. Hum Reprod. 2005;20:923-7.

14. Muttukrishna S, Suharjono $H$, McGarrigle $H$, Sathanandan M. Inhibin B and anti-Mullerian hormone: markers of ovarian response in IVF/ICSI patients? BJOG. 2004;111:1248-53. 
15. Fiçicioglu C, Kutlu T, Baglam E, BakacakZ. Early follicular antimüllerian hormone as an indicator of ovarian reserve. Fertil Steril, 2006;85:592-6.

16. Smeenk JM, Sweep FC, Zielhuis GA, Kremer. Antimüllerian hormone predicts ovarian responsiveness, but not embryo quality or pregnancy, after in vitro fertilization or intracyoplasmic sperm injection Fertil Steril. 2007;87:223-6.

17. Penarrubia J, Fabregues F, Manau D, Creus M, Casals $G$, Casamitjana $R$ et al. Basal and stimulation day 5 anti-Mullerian hormone serum concentrations as predictors of ovarian response and pregnancy in assisted reproductive technology cycles stimulated with gonadotropin-releasing hormone agonistgonadotropin treatment. Hum Reprod. 2005;20:91522.

18. Jayaprakasan K, Campbell B, Hopkisson J, Johnson I, Raine-Fenning N. A prospective, comparative analysis of anti-Müllerian hormone, inhibin-B, and three-dimensional ultrasound determinants of ovarian reserve in the prediction of poor response to controlled ovarian stimulation. Fertil Steril. 2010;93:855-64.

19. Nelson SM, Yates RW, Fleming R. Serum antiMüllerian hormone and FSH: prediction of live birth and extremes of response in stimulated cyclesimplications for individualization of therapy. Hum Reprod. 2007;22:2414-21.

20. Liao CC, Lee RK, Lin SY, Lin MH, Hwu YM. Outcomes of anti-Müllerian hormone-tailored ovarian stimulation protocols in in vitro fertilization/intracytoplasmic sperm injection cycles in women of advanced age. Taiwan J Obstet Gynecol 2016;55:239-43.

21. Tsakos E, Tolikas A, Daniilidis A, Asimakopoulos B. Predictive value of anti-müllerian hormone, folliclestimulating hormone and antral follicle count on the outcome of ovarian stimulation in women following GnRH-antagonist protocol for IVF/ET. Arch Gynecol Obstet. 2014;290:1249-53.

22. Demirtas GS, Demirtas O, Oztekin K, F Sendag, Bilgin O. Anti-Müllerian hormone and ovarian response in intrauterine insemination cycles: a prospective study. Kocatepe Tip Dergisi. 2014;15:8591.

23. Baykal B, Çelik C, Bastu E, Kutlu T, Batu P, Abalı R, Eren S. antral folikül sayısının in vitro fertilizasyon sonuçlari üzerine etkisi. J Clin Anal Med. 2014;5:3247. 